\title{
Purification and Serology of Rice Tungro Spherical and Rice Tungro Bacilliform Viruses*
}

\author{
Toshihiro Omura**, Yasuo Saito**, Tomio Usugi** and Hiroyuki Hibino** \\ 大村敏博**・斎藤康夫** • 宇杉富雄**・日比野啓行** : Rice tungro spherical \\ virus と rice tungro bacilliform virus の純化と血清関係*
}

Key Words : mixed virus infection, purification, physical properties.

Gálvez ${ }^{1)}$ reported that spherical particles about $30-33 \mathrm{~nm}$ in diameter were purified from rice plants with tungro disease. Saito ${ }^{2)}$ observed bacilliform and spherical particles in most of the specimens with tungro and similar diseases by electron microscopy. These particles were designated as rice tungro spherical virus (RTSV) and rice tungro bacilliform virus $(\mathrm{RTBV})^{3)}$. Rice waika virus (RWV) which occurred in Kyushu, Japan, is serologically related to $\mathrm{RTSV}^{2}$. Hibino et al. ${ }^{4}$ ) found that RTSV was transmitted by the vector Nephotettix virescens, but that RTBV was transmitted concomitantly only when RTSV was acquired previously or simultaneously, i.e., propagation of RTBV using plants solely infected with RTBV as inoculum was impossible. Since a large quantity of doubly-infected plants were available, such plants were used for virus purification.

A tungro isolate containing both RTBV and RTSV supplied by the International Rice Research Institute, Philippines, was propagated in rice plants (Oryza sativa L. cv. Taichung Native 1 ) by using viruliferous $N$. virescens. Infected plants were harvested about 40 days after inoculation and were stored at $-80 \mathrm{C}$. Clarification and partial purification were carried out according to the method applied for RWV $\mathrm{V}^{5)}$. Leaf extracts in $0.01 \mathrm{M}$ ethylenediaminetetraacetic acid (EDTA), pH 6.0 were heated at $40 \mathrm{C}$ for $1 \mathrm{hr}$. Virus particles were precipitated with $7 \%$ polyethylene glycol 6,000 plus $0.2 \mathrm{M}$ sodium chloride $(\mathrm{NaCl})$ containing $1 \%$ Triton $\mathrm{X}-100$. The resuspended virus particles were treated with $20 \%$ carbon tetrachloride, and were subjected to differential centrifugation $(96,000 \times g$ for $60 \mathrm{~min}$ at $4 \mathrm{C}$ in a Hitachi RP-40 rotor, then $10 \mathrm{~min}$ at $3,000 \times \mathrm{g})$. Supernatant was layered on 10-40\% linear sucrose density gradients (prepared in 0.01 $\mathrm{M}$ borate buffer $\mathrm{pH} 9.0$ (BB)) and centrifuged at $60,000 \times \mathrm{g}$ for $3 \mathrm{hr}$ at $4 \mathrm{C}$ in a Hitachi RPS-25 rotor. Tube contents were scanned at $\mathrm{A}_{254}$ and fractionated through

* Some of the investigations are part of a collaborative research project on "Studies on rice and legumes virus diseases in the Tropics" supported by the Tropical Agriculture Research Center, Japan.

** Institute for Plant Virus Research, Tsukuba Science City, Yatabe, Ibaraki 305, Japan 農林 水産省植物ウイルス研究所

1) Gálvez, G. E. (1968). Virology 35: 418-426. 2) Saito, Y. (1977). Tropical Agriculture Research Series

No. 10 : 129-135. Tropical Agricultural Research Center. Tsukuba, Ibaraki, Japan. 3) Saito, Y,, Hibino, H., Omura, T., and Usugi, T. (1981). Proc. 5th Int. Cong. Virology: 213. 4) Hibino, H., Saleh, N. and Roechan, M. (1979). Phytopathology 69: 1266-1268. 5) Usugi, T. and Saito, Y. (1975). Ann. Phytopath. Soc. Japan $41: 283$ (Abstr.) 


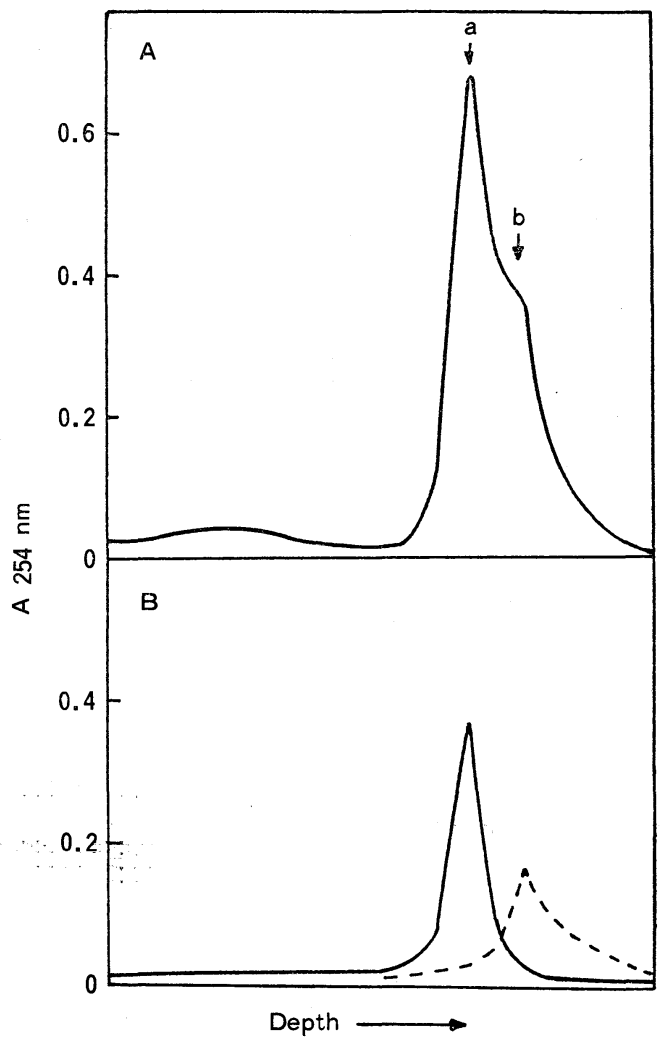

Fig. 1. Sucrose density-gradient profiles (A) of partially purified preparation from rice plants infected with both RTSV and RTBV, (B) following repeated sucrose density gradient centrifugations of peak "a" (solid line) and shoulder "b" (broken line).

an ISCO model UA5 ultraviolet analyzer. Typical density-gradient scanning pattern presented in Fig. 1A showed a peak (arrow with "a") containing RTSV, and a shoulder (arrow with "b") on the descending slope containing RTBV. Peak and shoulder fractions were separately collected, virus particles were pelletted by centrifugation, and were subjected to two additional density-gradient centrifugations (Fig. 1B). After three cycles of sucrose density-gradient centrifugation, RTSV was further purified by equilibrium centrifugation in $\mathrm{CsCl}$. When $3.273 \mathrm{~g}$ $\mathrm{CsCl}$ was dissolved in $4 \mathrm{ml}(45 \% \mathrm{w} / \mathrm{v})$ of the peak material in $0.01 \mathrm{M}$ phosphate buffer (PB), pH 7.0 and the suspension was centrifuged at $114,000 \times g$ for $40 \mathrm{hr}$ at $4 \mathrm{C}$ in a Hitachi RPS-40 rotor, a single band was formed at about two-thirds of the distance below the meniscus. The peak material was recovered, and $\mathrm{CsCl}$ was removed by two cycles of differential centrifugation. Final pellets were resuspended in $0.01 \mathrm{M}$ EDTA, pH 6.0 and such preparations contained isometric particles about $30 \mathrm{~nm}$ in diameter (Fig. 2).

Equilibrium centrifugation in $\mathrm{CsCl}$ was not appropriate for the purification of RTBV, because the particles were degraded during the two cycles of differential centrifugation applied to remove $\mathrm{CsCl}$ after the equilibrium centrifugation. After three cycles of sucrose density-gradient centrifugation, RTBV was further purified using antiserum to RWV whose titer was $1: 640$ in the precipitin ring interface test. Partially purified RTBV fraction was mixed with equal volume of the serum which was diluted to $1 / 100$ with $0.01 \mathrm{M} \mathrm{PB}, \mathrm{pH} 7.0$ containing $0.85 \% \mathrm{NaCl}$. The mixture was incubated for $1 \mathrm{hr}$ at $37 \mathrm{C}$, followed by over night incubation at $4 \mathrm{C}$. Preparations were negatively stained with neutralized phosphotungstic acid (PTA) and were examined under a Hitachi H-500 electron microscope. As shown in Fig. 3 contaminating RTSV particles were clumped and easily sedimented by low speed centrifugation. After two additional serum treatments final supernatant was layered on sucrose density-gradient, centrifuged, and fractionated as mentioned above. Virus was concentrated by high speed centrifugation and pellets were resuspended in $0.01 \mathrm{M}$ EDTA, pH6.0. Purified RTBV particles were $30-35 \mathrm{~nm}$ in width with varying length (Fig. 4). The length of the particles was measured and compared to that of particles in leaf dip preparations 

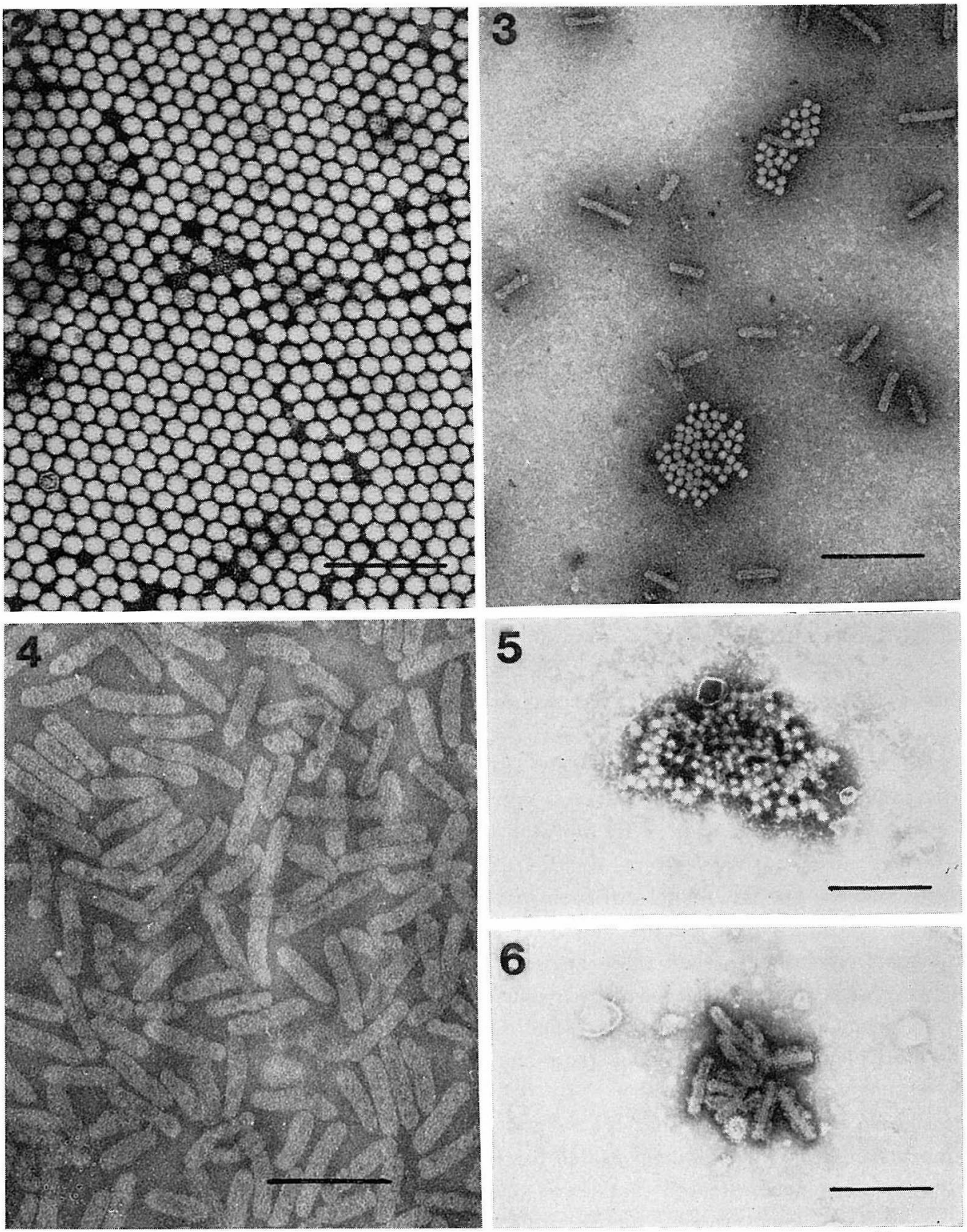

Figs. 2-6. Electron micrographs of RTSV and RTBV negatively stained with $2 \%$ phosphotungstate $\mathrm{pH}$ 7.0.

Fig. 2. Purified preparation of RTSV. Bar represents $200 \mathrm{~nm}$.

Fig. 3. Reaction of RTSV with the serum against RWV. Bar represents $300 \mathrm{~nm}$.

Fig. 4. Purified preparation of RTBV. Bar represents $200 \mathrm{~nm}$.

Fig. 5, 6. Immunoelectron microscopy preparation of diseased leaves on a grid previously mixed with serum of RTSV (Fig. 5) or RTBV (Fig. 6). Bars represent $300 \mathrm{~nm}$. 


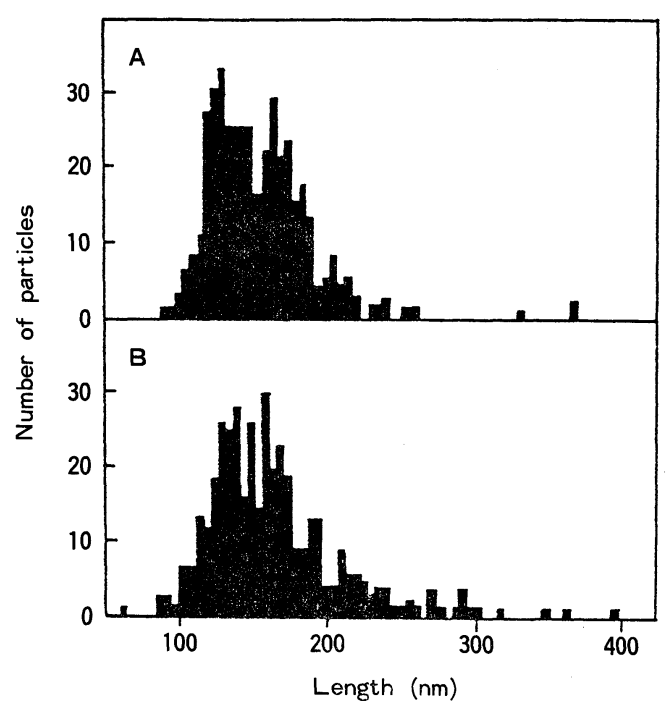

Fig. 7. Particle length distribution of RTBV in purified preparation (A) and in leaf dip preparation (B).
(Fig. 7A, B). Majority of the particles $(97 \%)$ were included in a major peak at $100-220 \mathrm{~nm}$ in purified preparations. There was no significant difference in the distribution pattern of the length between purified and leaf dip preparations.

Ratios of absorbance (260/280) for purified RTSV and RTBV were 1.75 and 1.11, respectively. Buoyant densities of the particles were estimated by equilibrium centrifugation in $\mathrm{CsCl}$. For RTBV, $2.154 \mathrm{~g} \mathrm{CsCl}$ was dissolved in 4 $\mathrm{ml}(35 \%, \mathrm{w} / \mathrm{v})$ of the purified preparation in $0.01 \mathrm{M} \mathrm{PB}, \mathrm{pH} 7.0$ and centrifuged at $114,500 \times g$ for $40 \mathrm{hr}$ at $4 \mathrm{C}$ in a Hitachi RPS -40 rotor. A single band was formed at about one-third of the distance below the meniscus. The density of the fraction was determined from the refractive index

using the method of Brakke ${ }^{6}$. Buoyant densities of RTSV and RTBV were $1.551 \mathrm{~g} /$ $\mathrm{cm}^{3}$ and $1.312 \mathrm{~g} / \mathrm{cm}^{3}$, respectively. The fact that RTBV formed a single band indicated that the buoyant density of RTBV was even, though the virus contained particles of various sizes.

Rabbits were immunized separately against RTSV and RTBV by an intramuscular injection with purified preparations emulsified with an equal volume of Freund's complete adjuvant as well as by repeated intravenous injections. In the precipitin ring interface test, antisera titers were $1 / 320$ and $1 / 2048$ against RTSV and RTBV, respectively. For double gel diffusion test, $0.8 \%$ agar in $0.01 \mathrm{M} \mathrm{PB}, \mathrm{pH} 7.6$ containing $0.85 \% \mathrm{NaCl}, 0.001 \mathrm{M} \mathrm{EDTA}$ and $0.05 \%$ sodium azide was used. No heterologous reactions occurred between these antisera and the two kinds of particles. Absence of serological relationship between these viruses was also confirmed by clumping technique ${ }^{7)}$ of immunoelectron microscopy. When antiserum was mixed with sap from doubly infected plant, only homologous reactions showed clumped particles with halos (Fig. $5,6)$.

Hibino et al. reported that RTSV and RTBV multiplied independently, though the presence of RTSV was indispensable for the transmission of $\mathrm{RTBV}^{4)}$. In the present study, it was demonstrated that there was no serological relationship between RTSV and RTBV. These results further indicate that RTSV and RTBV are independent virus, rather than multiparticle or satellite viruses ${ }^{8}$.

(Received June 28, 1982)

6) Brakke, M. K.(1967) Methods. in Virol. 2: 93-136. 7) Milne, R. G. and Luisoni, E. (1977). Methods. in Virol. 6: 265-281. 8) Lane, L. C. (1980). Nucleic Acids in Plants (Hall, T. C. and Davis, J. W. eds.). Vol. 2: $65-110$. C. R. C. Press, Florida. 